\title{
Article \\ Biodeterioration of Salón de Reinos, Museo Nacional del Prado, Madrid, Spain
}

\author{
Valme Jurado $^{1,+(\mathbb{C}}$, José Luis Gonzalez-Pimentel ${ }^{1,2,+}+\mathbb{D}$, Bernardo Hermosin ${ }^{1}$ and Cesareo Saiz-Jimenez ${ }^{1, *(\mathbb{D}}$ \\ 1 Instituto de Recursos Naturales y Agrobiologia, IRNAS-CSIC, 41012 Sevilla, Spain; \\ vjurado@irnase.csic.es (V.J.); pimentel@irnas.csic.es (J.L.G.-P.); hermosin@irnase.csic.es (B.H.) \\ 2 Laboratorio Hercules, Universidade de Evora, 7000-809 Evora, Portugal \\ * Correspondence: saiz@irnase.csic.es \\ + These authors contributed equally to this study.
}

Citation: Jurado, V.; Gonzalez-

Pimentel, J.L.; Hermosin, B.; Saiz-

Jimenez, C. Biodeterioration of Salón de Reinos, Museo Nacional del Prado, Madrid, Spain. Appl. Sci. 2021, 11, 8858. https://doi.org/10.3390/ app11198858

Academic Editor: Daniela Isola

Received: 23 August 2021

Accepted: 19 September 2021

Published: 23 September 2021

Publisher's Note: MDPI stays neutral with regard to jurisdictional claims in published maps and institutional affiliations.

Copyright: (c) 2021 by the authors. Licensee MDPI, Basel, Switzerland. This article is an open access article distributed under the terms and conditions of the Creative Commons Attribution (CC BY) license (https:// creativecommons.org/licenses/by/ $4.0 /)$.

\begin{abstract}
The Salón de Reinos, a remnant of the 17th century Palacio del Buen Retiro, was built as a recreational residence under the reign of Felipe IV between 1632 and 1640 and was the main room for the monarch's receptions. This Salon owes its name to the fact that the coats of arms (shields) of the 24 kingdoms that formed Spain in Felipe IV's time were painted on the vault, above the windows. In addition, the ceiling shows an original decorative composition. The painted ceiling and window vaults showed deterioration evidenced by fissures, water filtration, detachments of the paint layer, and black stains denoting fungal colonization related to humidity. Ten strains of bacteria and 14 strains of fungi were isolated from the deteriorated paintings. Their biodeteriorative profiles were detected through plate assays. The most frequent metabolic functions were proteolytic and lipolytic activities. Other activities, such as the solubilization of gypsum and calcite and the production of acids, were infrequent among the isolates.
\end{abstract}

Keywords: biodeterioration; mural paintings; bacteria; fungi; biocide

\section{Introduction}

The earliest known examples of wall paintings are found in Crete and in Egyptian tombs. The Etruscan necropolis of Tarquinia, included in the UNESCO World Heritage list, contains a large number of decorated tombs, the oldest of which date from the 7th century BC. Examples of extraordinary Roman wall paintings are found in the magnificent Villa dei Misteri (1st century BC) in Pompeii. The late medieval period and the Renaissance are examples of the noticeable use of wall paintings, particularly in Italy, where most churches display this type of decoration.

Wall paintings can be affected by various problems-environmental pollution, excessive humidity, water seepage from the ceilings, and poor quality of materials and construction methods-all contributing to the deterioration of the murals. In wall paintings, different phenomena can be observed; the most common include cracks, detachment of the painted surface, efflorescence formation, color changes and growth of films of microbial origin.

In the initial stages of colonization, the growth of microorganisms in a wall painting causes only aesthetic damage, as little or no alteration of the painted surface occurs. Subsequently, the cells and hyphae penetrate the paint layer, and the chemical attack results in pitting, peeling, cracking and loss of paint. To this damage is added that caused by microbial metabolites, which alter the original color and sometimes produce red, green or black pigmentations [1-5].

Deteriorated wall paintings contain a variety of hygroscopic salts, including carbonates, chlorides, nitrates and sulfates, which form efflorescences on their surfaces. This means that, in many cases, efflorescence deposits in murals mimic the conditions found 
in extreme habitats, favoring the growth of halophilic microorganisms. Due to its deteriorating effect, saline efflorescence in wall paintings is a common problem and can create micro-niches with a salt concentration high enough to allow the growth of halophilic Archaea, as demonstrated by Piñar et al. [6] in two deteriorated wall paintings subjected to different environmental and climatic conditions: the Chapel of Herberstein Castle (Austria) and the Tomb of Servilia in the Necropolis of Carmona (Spain).

Of particular importance is the colonization and growth of bacteria in wall paintings. Gorbushina et al. [7] studied the deterioration of the wall paintings in the church of St. Martin in Germany. In these paintings, the authors isolated numerous species of Arthrobacter, Bacillus and related genera (Paenibacillus, Gracilibacillus, Salibacillus), producers of spores, in addition to Staphylococcus and Nocardioides.

However, the most frequent and conspicuous biodeterioration phenomenon is the colonization of wall paintings by fungi, since they generally produce black or green colored patinas. In modern wall paintings from La Rábida Monastery, Spain, the most abundant fungus was Cladosporium sphaerospermum, followed by Engyodontium album, recently transferred to the novel genus Parengyodontium album [8] and Aspergillus versicolor. Less frequent were Acremonium charticola, Alternaria alternata, Botrytis cinerea, Cunninghamella echinulata, Phoma glomerata, etc. [9]. In addition, the mite Tyrophagus palmarum was found in the paintings, feeding on bacteria and fungi.

Karpovich-Tate and Rebrikova [10] investigated the biodeterioration of wall paintings at the Pafnutii-Borovskii Monastery, Russia, finding that Parengyodontium album comprised $90 \%$ of the fungi isolated from the deteriorated stone, while Cladosporium sphaerospermum accounted for $65 \%$ of the total isolates from the painted surfaces.

Gorbushina and Petersen [11] studied various wall paintings in Germany and found Acremonium spp., Cladosporium spp., Verticillium spp., Aspergillus sydowii, Aureobasidium pullulans, Parengyodontium album, Scopulariosis brevicaulus, Beauveria sp. and Chrysosporium sp. The walls commonly included springtails, mites, flies and spiders. Arthropod remains were frequently found in all investigated locations, and most of them were colonized by fungi. In fact, most of the available data suggest that fungi in wall paintings are related to arthropods [12]. Entomopathogenic fungi, in particular Parengyodontium album, are common on wall paintings from different countries [7,9-12].

In wall paintings, certain ecological conditions prevail, such as a low concentration of carbon sources, variable-to-high humidity levels and, generally low temperatures. Under these conditions the growth of microorganisms is possible, in most cases forming a biofilm or microbial film composed of many species of bacteria, archaea, fungi, etc. [13-16].

The possible carbon sources in wall paintings are protein-type binders, such as casein, animal glue, egg, etc., and some pigments, as well as synthetic polymers used for preservation. The destructive activity of microorganisms in the paint film is not limited to its surface, but penetrates deep into the layer of paint and plaster, and its destructive effect can be even more intense in the deeper layers than on the surface.

The use of binders by microorganisms as a nutritional source leads to deterioration and consequently, to the detachment of pigment particles, devoid of any binding effect. This process was reported by Piñar et al. [6], who noticed the damage caused during restoration of the Chapel of Herberstein Castle, Austria, with 14th century frescoes. Around 1580, the frescoes were covered with plaster for a few hundred years. Restoration works were carried between 1942 and 1949, and the plaster layer was removed. In this restoration, the paints were fixed with casein-water (1:10), and casein was also added to the mortar for consolidation. Fungal growth started only five days after the application of casein, and the ceiling had to be cleaned again. However, after this restoration, the chapel was abandoned and used as a warehouse until the mid-1990s. At the beginning of the 21st century, the paintings showed considerable microbial growth, including loss of consistency in many areas as well as severe discoloration, with the formation of saline efflorescences and pink pigmentation due to microbial attack. This is an example of how erroneous restoration protocols can damage wall paintings. Therefore, it is of the utmost importance to know the 
biodeteriorative activity of the microorganisms isolated from mural paintings in order to decide which treatments can be safely used in restoration.

\section{Materials and Methods}

\subsection{Historic Overview of Salón de Reinos}

On 25 July 2021, UNESCO added the Paseo del Prado and Buen Retiro, a landscape of Arts and Sciences (Madrid, Spain) to the World Heritage List. This Paseo includes avenues, fountains, gardens and many buildings, a few of them dedicated to the arts and sciences: Museo Nacional del Prado, Museo Nacional Centro de Arte Reina Sofía, Museo Thyssen-Bornemisza, Museo Nacional de Antropología, Museo Naval, and Museo Nacional de Artes Decorativas.

The Museo Nacional del Prado is a museum campus composed of several buildings. Two of them, Casón del Buen Retiro and Salón de Reinos, are remnants of the 17th century Palacio del Buen Retiro. This palace was built as a recreational residence under the reign of Felipe IV, between 1632 and 1640. The palace was seriously damaged during the War of Independence (1808-1812), and part of the ruined palace was demolished in 1816-1819, under Fernando VII. Other palace buildings were demolished in 1868, except the Casón del Buen Retiro, an old ballroom and party hall, and the Salón de Reinos, the main room for the monarch's receptions. A program to expand the Museo Nacional del Prado integrated this Salón, used as an Army Museum from 1841 to 2005, into the museum properties.

In the 17th century, the Salón de Reinos housed famous paintings (Velázquez, Zurbarán, and others), now deposited in the Museo Nacional del Prado. The Salón, a room $34.6 \mathrm{~m}$ long, $10 \mathrm{~m}$ wide and $8 \mathrm{~m}$ high, owes its name to the fact that the coats of arms (shields) of the 24 kingdoms that formed Spain in Felipe IV's time were painted on the vault, above the windows (Figure 1).

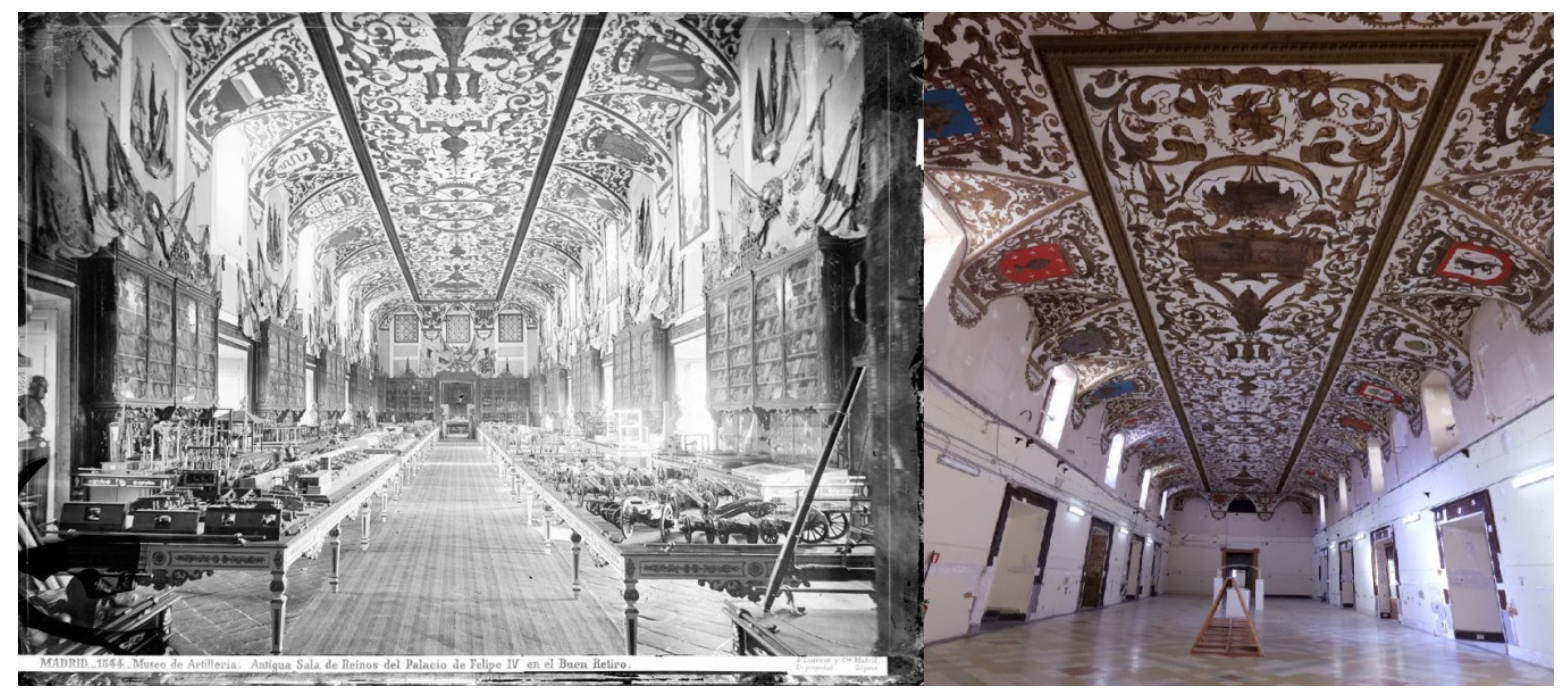

Figure 1. Salón de Reinos, Museo Nacional del Prado, Madrid, Spain. (Left), as Army Museum. Photo J. Laurent y Cia. Archivo Ruiz Vernacci. IPCE, Ministerio de Cultura y Deporte. (Right), before restoration. Photo Juan Aguilar, Ágora S.L.

The conservation of Salón de Reinos was poor (Figure 2). The painted ceiling and window vaults showed deterioration evidenced by fissures, water filtration (Figure 2B), detachments of the paint layer (Figure 2C,D) and fungal colonization related to humidity (Figure 2D,E). Other issues include the urgency of the design and construction of the Salón, the use of low-quality materials and, above all, the different uses and adaptations of the building over 400 years, with rehabilitation interventions that caused scratching and hiding of the paintings in the walls and repainting of the ceiling (Figure 2A). 


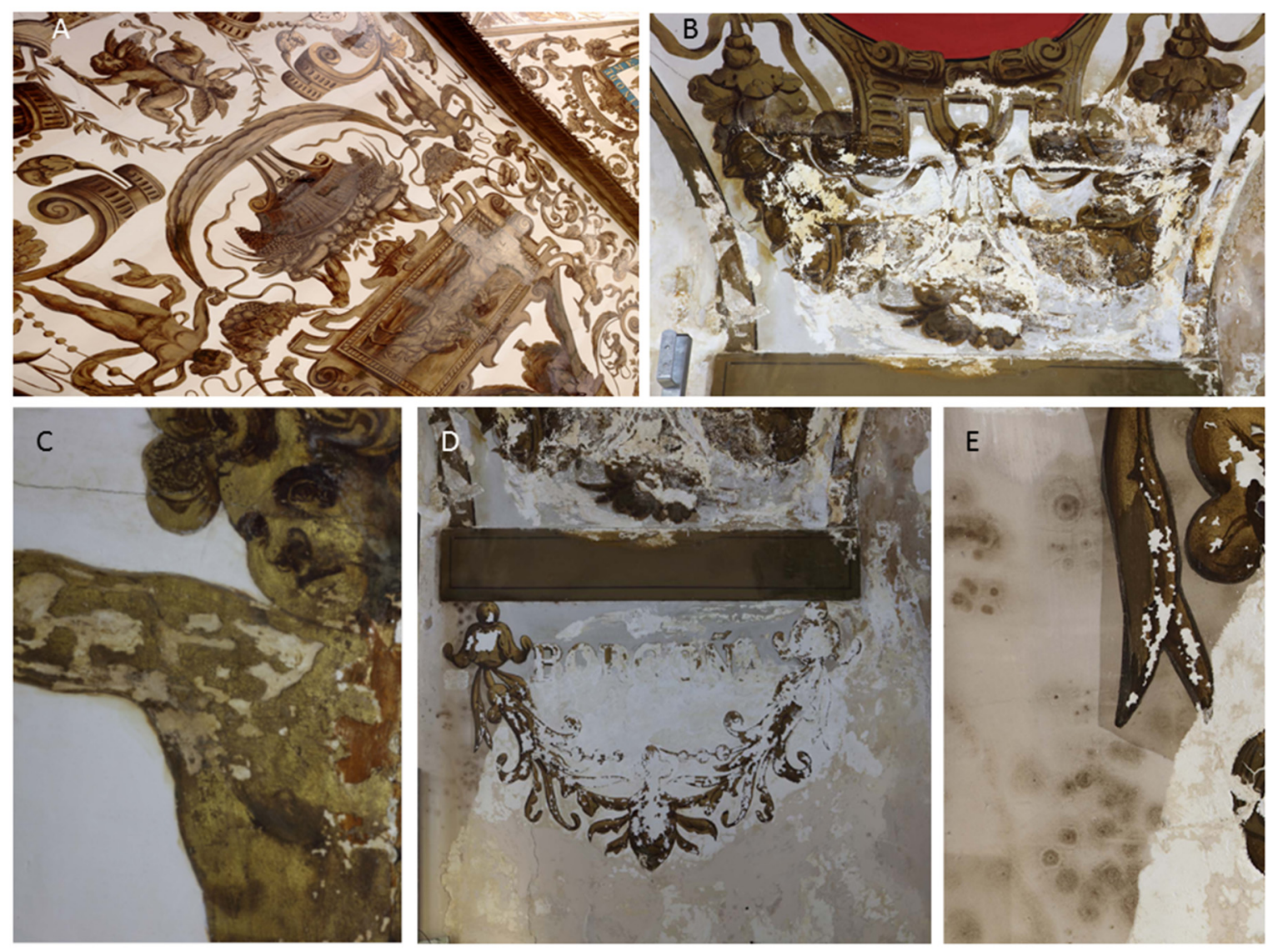

Figure 2. Salón de Reinos, Museo Nacional del Prado, Madrid, Spain. (A) Detail of the ceiling showing repaints. (B) Deterioration produced by a recent water leak. (C) Paint detachment in the ceiling. (D) Burgundy shield (sample M2) with fungal growth and painting detachments. (E) Detail of fungal growth in (D). Photos provided by Ágora S.L.

While the original decorative composition on the ceiling was preserved almost entirely, on the walls the decoration was covered by plastering. The scratching of all the wall surfaces to apply a new plaster caused damage to a large number of the compositional elements as well as physical deterioration of the pictorial layers and the gilding.

The ceiling was subject to repainting that covered almost its entire surface (Figure 2A). These patches, although they appeared as a homogeneous stratum, had different chronologies in the 19th and 20th centuries. At the beginning of the 20th century, a general repainting of the entire ceiling was carried out; tempera was used mainly for its application, and occasionally a greasy temper inside the shields was applied. The repaints were dated "14 April 1912".

Beneath the repainting, there was a deteriorated and detached original surface (pictorial layer and gilding) with an often significant degree of powder and detachment in the coats of arms or wide gaps due to different textures (Figure 2A). The natural aging of the pictorial layer was manifested mainly in the ceiling gilding, where the polymerization of the oils used in the glazes contributed to the generalized micro-exfoliation observed in large areas. In addition, on the ceiling paintings and on the repaintings, a thick dark layer of dust, a consequence of environmental pollution, appeared adhered to the surfaces.

Therefore, it was decided that Salón de Reinos needed rehabilitation and adaptation to meet modern museum requirements, and an international contest for project designs was launched in 2016. This was won by Foster + Partners and Rubio Arquitectura.

An unpublished study of Ágora Restauraciones de Arte, S.L., Madrid, for the Museo Nacional del Prado, provides information on Salón de Reinos mortars and paintings. The report stated the presence of a coarse mortar of gypsum and clays and fine-grained gypsum plasters, with binders of animal glue, linseed oil, pine resin, sandarac and turpentine of 
Venice. The paintings were made of gold leaf (gilding), a mixture of cobalt and azurite glaze or natural lapis lazuli (blue color), and red lead (red color). The binders are excellent nutrient sources of carbon and nitrogen for microorganisms. This indicates the need to carry out a detailed study on the microbial populations and the possible use of the components of the mortars and paintings before carrying out a restoration.

This paper reports on the biodeterioration of Salón de Reinos before the restoration. The aims were focused on the isolated microorganisms and their ability to degrade cultural heritage materials and products commonly used in restoration works.

\subsection{Sampling}

The samples studied were located in the ceiling of Salón de Reinos (Table 1 and Figure 2). Sampling was restricted due to the protection of the monument, and only $<500 \mathrm{mg}$ from three samples were available for the study.

Table 1. Description and location of the samples studied.

\begin{tabular}{ccc}
\hline Sample & Description & Location \\
\hline M1 & Surface dust & S-3. Mexico shield \\
M2 & Black stains & S-4. Burgundy shield \\
M3 & Black stains & S-02. Between Galicia and Murcia shields \\
\hline
\end{tabular}

\subsection{Isolation of Culturable Microorganisms}

The samples ( $<500 \mathrm{mg}$ per sample) were homogenized in sterile saline solution $(0.9 \%$ $\mathrm{NaCl} w / v$ ) and inoculated into culture media such as Tryptone-Soy Agar (TSA) for bacteria and Malt Extract Agar (MEA) for fungi. The plates were incubated at $28^{\circ} \mathrm{C}$ for $24-72 \mathrm{~h}$ to allow the growth of bacteria, and at $25^{\circ} \mathrm{C}$ for $4-5$ days for fungi. Individual colonies with different color, size, border shape, and texture were isolated and inoculated in TSA and MEA, respectively. Once the cultures were obtained from the colonies, the purity of each isolate was confirmed microscopically. The bacteria were conserved at $-80^{\circ} \mathrm{C}$ in cryovials (Microbank), and the fungi were preserved at $4{ }^{\circ} \mathrm{C}$ on MEA slants until studied.

\subsection{DNA Extraction and Amplification}

The extraction of DNA from the strains was carried out from bacterial biomass and fungal mycelia. The biomass was transferred to a $1.5 \mathrm{~mL}$ Eppendorf tube containing $500 \mu \mathrm{L}$ of the TNE extraction buffer (10 mM Tris-HCl, $100 \mathrm{mM} \mathrm{NaCl}, 1 \mathrm{mM}$ EDTA; $\mathrm{pH}$ 8 ) and 2 and $4 \mathrm{~mm}$ glass beads. The mixture was homogenized using a stirrer (Fast Prep$24)$, applying two cycles of $45 \mathrm{~s}$ at a speed of $4.5 \mathrm{~m} / \mathrm{s}$. The proteins were removed by adding $50 \mu \mathrm{L}$ of sodium dodecyl sulfate $(10 \% w / v)$ and $70 \mu \mathrm{L}$ of proteinase $\mathrm{K}(10 \mathrm{mg} / \mathrm{mL})$, and the mixture was incubated at $50{ }^{\circ} \mathrm{C}$ for one hour. DNA was purified with $750 \mu \mathrm{L}$ phenol-chloroform-isoamyl alcohol (25:24:1). The mixture was centrifuged at $8000 \mathrm{rpm}$ for $5 \mathrm{~min}$. The supernatant obtained was subjected to further purification with $450 \mu \mathrm{L}$ of chloroform-isoamyl alcohol (24:1). Centrifugation was repeated under identical conditions, and the supernatant was collected. DNA precipitation was performed by adding $50 \mu \mathrm{L}$ of $3 \mathrm{M}$ sodium acetate ( $\mathrm{pH}$ 5.2) and $1 \mathrm{~mL}$ of absolute ethanol. To promote precipitation, the mixture was incubated at $-20^{\circ} \mathrm{C}$ for $30 \mathrm{~min}$ and centrifuged at $13,000 \mathrm{rpm}$ for $10 \mathrm{~min}$. The precipitate was washed with ethanol $(70 \%)$ and allowed to dry at room temperature. Finally, the precipitated DNA was then dissolved in $100 \mu \mathrm{L}$ of sterile ultra-pure water.

The resulting DNA concentration in the extraction products was quantified using a Qubit 2.0 fluorimeter (Invitrogen), following the manufacturer's instructions. The products were stored at $-80^{\circ} \mathrm{C}$ until use.

For the identification of bacteria, the 16S rRNA gene was amplified, and for fungi, the ITS region was between the small and large subunit of ribosomal RNA, 18S rRNA and 28S rRNA (ITS1 and ITS2, respectively). The primers 616F (5'-AGA GTT TGA TYM TGG CTC AG-3') [17] and 1522R (5'-AAG GAG GTG ATC CAG CCG CA-3') [18] were used for 
bacteria, and the primers ITS1 (5'-TCC GTA GGT CCT GAA GCG G-3') and ITS4 (5'-TCC TCC GCT TAT TGA TAT GC-3') described by White et al. [19] were used for fungi.

Each PCR reaction was run in a final volume of $50 \mu \mathrm{L}$. The reaction mixture consisted of $5 \mu \mathrm{L}$ of $10 \mathrm{X}$ reaction buffer [ $750 \mathrm{mM}$ Tris- $\mathrm{HCl}\left(\mathrm{pH}\right.$ 9), $500 \mathrm{mM} \mathrm{KCl}, 200 \mathrm{mM}\left(\mathrm{NH}_{4}\right)_{2} \mathrm{SO}_{4}$ ], $2 \mu \mathrm{L}$ of $50 \mathrm{mM} \mathrm{MgCl}_{2}, 0.5 \mu \mathrm{L}$ of each $50 \mu \mathrm{M}$ primer (Invitrogen Life Technologies), $5 \mu \mathrm{L}$ of deoxyribonucleotide mix (dNTPs) (Bioline GC Biotech, Alphen aan den Rijn, The Netherlands), $2 \mathrm{mM}$ each, $0.25 \mu \mathrm{L}$ of Taq polymerase enzyme $(5 \mathrm{U} / \mu \mathrm{L})$ (Biotools M\&B Labs, Madrid, Spain), and 10-20 ng of template DNA; the reaction volume was completed with sterile ultra-pure water. All samples were run in duplicate, and two negative controls, containing sterile ultra-pure water replacing template DNA, were included for each batch of reactions. The PCR reactions were performed in an iCycler thermal cycler (Bio-Rad, CA, USA). The PCR protocol used for the $16 \mathrm{~S}$ rRNA gene region consisted of the following steps: 2 min of initial denaturation at $94{ }^{\circ} \mathrm{C} ; 35$ cycles composed of $20 \mathrm{~s}$ at $94{ }^{\circ} \mathrm{C}, 20 \mathrm{~s}$ at $55^{\circ} \mathrm{C}$, and $2 \mathrm{~min}$ at $72{ }^{\circ} \mathrm{C}$; followed by a 10 minute final extension at $72{ }^{\circ} \mathrm{C}$. The protocol used for the amplification of the ITS regions consisted of $2 \mathrm{~min}$ of initial denaturation at $95^{\circ} \mathrm{C}$; 35 cycles consisting of $1 \mathrm{~min}$ at $95^{\circ} \mathrm{C}, 1 \mathrm{~min}$ at $50{ }^{\circ} \mathrm{C}$, and $1 \mathrm{~min}$ at $72{ }^{\circ} \mathrm{C}$; followed by a $5 \mathrm{~min}$ final extension at $72{ }^{\circ} \mathrm{C}$. To confirm the positive result of the PCR amplifications, horizontal SeaKem agarose gel electrophoresis (FMC Bioproducts, Rockland, ME, USA) was performed at $1 \%(w / v)$ with TAE $0.5 X$ buffer $(20 \mathrm{mM}$ Tris, $10 \mathrm{mM}$ glacial acetic acid, 0.5 mM EDTA).

\subsection{DNA Sequencing}

The PCR products corresponding to the bacterial and fungal strains were sequenced in duplicate at Secugen (CIB-CSIC, Madrid), with an ABI 3700 capillary sequencer (Applied Biosystems, Foster City, CA, USA) using the same primers as for PCR. The sequences obtained were edited with the BioEdit 7.2.5 program [20], establishing the consensus sequences for each strain analyzed. Homology searches of the sequences were performed using the BLASTn algorithm [21]. The fungal sequences were compared with the existing sequences from the National Center for Biotechnology Information (NCBI) databases, Standard Nucleotide and ITS Reference Sequence, and the fungi were identified according to the best matches. However, the ITS marker alone for identification does not discriminate at the species level in certain fungal genera such as Aspergillus and Penicillium, and it may be necessary to sequence one or more protein-coding genes to obtain a more precise identification at the species level [22]. The bacterial sequences were also compared using the NCBI Standard Nucleotide database and the EZBioCloud 16S database [23], which assigns the closest cultivated type species. All sequences were deposited in the NCBI GenBank database (http:/ / www.ncbi.nlm.nih.gov/genbank/, accessed on 23 August 2021).

\subsection{Biodeteriorative Activity of the Isolates}

The strains were tested in different culture media to know their potential mortar and paint biodeterioration. Table 2 details the culture media tested for the analyses.

Mortar deterioration was tested for solubilization of gypsum and calcite (CaS and GyS media). Binder deterioration was tested by means of casein and gelatin hydrolysis ( $\mathrm{CH}$ and $\mathrm{GH}$ media). The degradation of oils was tested with the lipolytic activity ( $\mathrm{LH}$ medium). The production of acid or alkali (AAP medium) was also qualitatively measured. All tests were carried out in triplicate at $28^{\circ} \mathrm{C}$ for bacteria and $25^{\circ} \mathrm{C}$ for fungi for 1 week. 
Table 2. Culture media and metabolic activities analyzed.

\begin{tabular}{cccc}
\hline Medium & Composition * & Analysis & Reference \\
\hline $\mathrm{GH}$ & TSA/MEA $+1 \%$ gelatin & Proteolytic activity & {$[24]$} \\
$\mathrm{LH}$ & $1 \%$ Tween 80 & Lipolytic activity & {$[25]$} \\
$\mathrm{CH}$ & Nutrient Casein Agar & Proteolytic activity & {$[26]$} \\
$\mathrm{CaS}$ & $\mathrm{TSA} / \mathrm{MEA}+1 \% \mathrm{CaCO}_{3}$ & Calcite solubilization & {$[24]$} \\
$\mathrm{GyS}$ & $\mathrm{TSA} / \mathrm{MEA}+1 \% \mathrm{CaSO}_{4}$ & Gypsum solubilization & {$[24]$} \\
$\mathrm{AAP}$ & Czapek-Dox broth & Acid/Alkali production & {$[26]$} \\
\hline *TSA/MEA TSA or MEA was used for testing bacterial or fungal strains, respectively.
\end{tabular}

\section{Results and Discussion}

A total of 10 strains of bacteria and 14 of fungi were isolated. Table 3 shows the identification of the bacteria isolated from the paintings and dust, and Table 4 shows the identification of fungi.

Table 3. Identification of bacteria isolated from Salón de Reinos.

\begin{tabular}{ccll}
\hline Samples & Accession Number & Strains & Identification and Accession Number (\% Identity) \\
\hline \multirow{2}{*}{ M1 } & MZ827450 & MP1B-1 & Priestia aryabhattai EF114313 (99.7\%) \\
& MZ827451 & MP1B-2 & Bacillus tequilensis AYTO01000043 $(99.9 \%)$ \\
& MZ827452 & MP1B-3 & Bacillus paralicheniformis KY694465 $(99.7 \%)$ \\
\hline \multirow{3}{*}{ M2 } & MZ827453 & MP2B-2 & Bacillus frigoritolerans AM747813 $(99.7 \%)$ \\
& MZ827454 & MP2B-3 & Bacillus paralicheniformis KY694465 (99.7\%) \\
& MZ827455 & MP2B-4 & Bacillus cereus AE016877 (99.6\%) \\
\hline \multirow{3}{*}{ M3 } & MZ827456 & MP3B-1 & Cytobacillus oceanisediminis GQ292772 (99.4\%) \\
& MZ827457 & MP3B-2 & Streptomyces thinghirensis FM202482 (99.6\%) \\
& MZ827458 & MP3B-3 & Priestia endophytica AF295302 $(99.4 \%)$ \\
\hline
\end{tabular}

Table 4. Identification of fungi isolated from Salón de Reinos.

\begin{tabular}{|c|c|c|c|}
\hline Samples & Accession Number & Strains & Identification and Accession Number (\% Identity) \\
\hline \multirow{8}{*}{ M1 } & MZ827828 & MP1B-4 & Penicillium chrysogenum MF422150 (100\%) \\
\hline & MZ827829 & MP1B-5 & Penicillium chrysogenum MF422150 (99.7\%) \\
\hline & MZ827830 & MP1H-1 & Alternaria angustiovoidea MK910070 (100\%) \\
\hline & MZ827831 & MP1H-2 & Cladosporium xylophilum MH863875 (100\%) \\
\hline & MZ827832 & MP1H-3 & Penicillium fuscoglaucum NR163669 (100\%) \\
\hline & MZ827833 & MP1H-4 & Mucor racemosus NR126135 (99.0\%) \\
\hline & MZ827834 & MP1H-5 & Cladosporium macrocarpum NR119657 (100\%) \\
\hline & MZ827835 & MP1H-6 & Penicillium chrysogenum MF422150 (100\%) \\
\hline M2 & MZ827836 & MP2H-1 & Stagonosporopsis lupini NR160205 (98.3\%) \\
\hline \multirow{5}{*}{ M3 } & MZ827837 & MP3B-5 & Penicillium chrysogenum MF422150 (99.7\%) \\
\hline & MZ827838 & MP3H-1 & Mucor racemosus NR126135 (99.0\%) \\
\hline & MZ827839 & МР3H-2 & Penicillium chrysogenum MF422150 (100\%) \\
\hline & MZ827840 & MP3H-3 & Penicillium chrysogenum MF422150 (100\%) \\
\hline & MZ827841 & MP3H-5 & Botryotrichum domesticum NR169944(98.6\%) \\
\hline
\end{tabular}

\subsection{Ecology of Bacterial Isolates}

The abundance of strains of the genus Bacillus and bacteria phylogenetically related to that genus (Cytobacillus, Peribacillus, Priestia), which produce spores, as well as the species Streptomyces thinghirensis, was remarkable. Most of these species were not previously found on wall paintings (e.g., Priestia aryabhattai, Bacillus tequilensis, Bacillus paralicheniformis, Priestia endophyticus) but on plants and soils [27-31]. The habitat of Streptomyces thinghirensis is also the soil rhizosphere [32]. The possibility of the transport of spores by the air should 
not be excluded, given the proximity of Salón de Reinos to the Retiro Park and Botanical Garden.

Other bacilli (Bacillus cereus, Bacillus frigoritolerans) were commonly found in wall paintings [7,33-38]. Cytobacillus oceanisediminis was previously found in caves and mines $[39,40]$.

The abundance of bacteria from the genus Bacillus and other related genera (Paenibacillus, Gracilibacillus, Salibacillus) on wall paintings is not new, since previous research reported their presence and isolation from the deteriorated wall paintings in the church of St. Martin in Germany [7]. The unique presence of spore-forming bacteria in the wall paintings was noticeable. The dominance of bacilli may be due to their ability to survive for a long time as spores, since in periods of favorable conditions (humidity), small populations of bacilli produce a high number of spores, using these favorable conditions for further growth. These spores tend to germinate rapidly in culture media.

Laiz et al. [38] isolated 11 species of Bacillus, four of Paenibacillus, three species of Staphylococcus, two of Micrococcus and Cellulomonas, and one of Streptomyces and Arthrobacter from the mural paintings located in Servilia tomb, Necropolis of Carmona, Spain. Most of these strains presented a facultative oligotrophic behavior coincident with the limitation of nutrients in the mural paintings.

Tomassetti et al. [35] investigated the Tomba degli Scudi in Tarquinia, Italy, after receiving a conventional treatment with Preventol. Subsequently, a number of bacteria and fungi were isolated from the walls, including Bacillus frigoritolerans, Bacillus simplex, Fictibacillus barbaricus, Fictibacillus phosphorivorans, and Bacillus cereus, as well as an unidentified fungus. Two of these bacteria match those found in the Salón de Reinos. The authors concluded that the treatment was not totally effective, since a few spores remained active and were able to grow in laboratory culture media.

\subsection{Ecology of Fungal Isolates}

The deterioration of wall paintings by fungi is a subject that has occupied the attention of restorers and microbiologists, even more than the biodeterioration induced by bacteria. For this reason, there is abundant literature on the topic, which reflects the harmful effects of the colonization of frescoes and wall paintings in churches, monasteries, tombs, and catacombs [6,7,9-11,34-37].

Penicillium chrysogenum is one of the fungi most frequently isolated in wall paintings, and obvious signs of biodeterioration have been found on the surface of paintings [9,41-43] Therefore, their abundance in the Salón de Reinos paintings is not surprising.

The cosmopolitan genus Alternaria is made up of multiple saprophytic and pathogenic plant species. Woudenberg et al. [44] considered Alternaria angustiovoidea to be a synonym for Alternaria alternata, based on the study of the genome and comparison of the transcriptome and molecular phylogenies. Alternaria alternata is widespread on wall paintings $[36,41,43]$.

The remaining fungi from Table 4 (Cladosporium xylophilum, C. macrocarpum, Penicillium fuscoglaucum, Mucor racemosus, Stagonosporopsis lupini) were commonly isolated from plants and foods [45-49], and Botryotrichum domesticum from a house [50]. As far as we know, no reports on their presence on wall paintings have been published, other than for $C$. macrocarpum [41,51].

\subsection{Metabolic Activities of Bacterial and Fungal Isolates}

Trovão and Portugal [5] described the importance of using plate assays for identifying the deteriorative abilities of microorganisms in order to evaluate the potential risks to mural paintings. The isolation of microorganisms and plate assays are widely used by microbiologists in deterioration studies to provide insight into their attack on different types of materials [5,14,26,52-55]. Table 5 presents the metabolic activities of the isolates and their role in the hydrolysis of gelatin, casein, and lipids, the solubilization of gypsum and calcite, and acid production (Figure 3). 
Table 5. Microbial activities of bacteria and fungi isolated from Salón de Reinos.

\begin{tabular}{|c|c|c|c|c|c|c|}
\hline Strain Reference & $\mathrm{GH}^{*}$ & LH & $\mathrm{CH}$ & GyS & $\mathrm{CaS}$ & AAP \\
\hline Priestia aryabhattai, strain MP1B-1 & - & + & + & - & - & + \\
\hline Bacillus tequilensis, strain MP1B-2 & - & + & - & + & - & - \\
\hline Bacillus paralicheniformis, strain MP1B-3 & + & - & - & - & - & - \\
\hline Penicillium chrysogenum, strain MP1B-4 & - & - & - & - & - & - \\
\hline Penicillium chrysogenum, strain MP1B-5 & - & + & + & - & - & - \\
\hline Alternaria angustiovoidea, strain MP1H-1 & - & - & - & - & - & - \\
\hline Cladosporium xylophilum, strain MP1H-2 & - & + & - & - & - & - \\
\hline Penicillium fuscoglaucum, strain MP1H-3 & - & + & + & - & + & - \\
\hline Mucor racemosus, strain $\mathrm{MP} 1 \mathrm{H}-4$ & - & - & - & - & - & - \\
\hline Cladosporium macrocarpum, strain MP1H-5 & - & + & - & - & - & - \\
\hline Penicillium chrysogenum, strain MP1H-6 & - & - & + & - & + & - \\
\hline Bacillus frigoritolerans, strain MP2B-2 & - & + & + & + & - & + \\
\hline Bacillus paralicheniformis, strain MP2B-3 & + & - & - & - & - & - \\
\hline Bacillus cereus, strain MP2B-4 & - & - & - & - & - & - \\
\hline Stagonosporopsis lupini, strain MP2H-1 & - & - & + & - & - & - \\
\hline Cytobacillus oceanisediminis, strain MP3B-1 & - & - & + & - & - & - \\
\hline Streptomyces thinghirensis, strain MP3B-2 & - & + & + & - & - & - \\
\hline Priestia endophytica, strain MP3B-3 & - & + & + & + & - & + \\
\hline Bacillus frigoritolerans, strain MP3B-6 & - & + & + & - & - & + \\
\hline Penicillium chrysogenum, strain MP3B-5 & - & - & + & - & - & - \\
\hline Mucor racemosus, strain MP3H-1 & - & - & - & - & - & - \\
\hline Penicillium chrysogenum, strain MP3Н-2 & - & + & + & - & - & - \\
\hline Penicillium chrysogenum, strain MP3H-3 & - & - & + & - & - & - \\
\hline Botryotrichum domesticum, strain MP3H-5 & - & + & - & - & - & - \\
\hline
\end{tabular}

* GH, gelatin hydrolysis; CH, casein hydrolysis; LH, lipolytic activity; GyS, gypsum solubilization; CaS, calcite solubilization; AAP, acid/alkali production.

The most conspicuous activities, with a greater number of positive strains, were the hydrolysis of casein and lipids, and to a lesser extent, the hydrolysis of gelatin and the production of acids and alkalis.

The activity of Penicillium chrysogenum stands out, with six out of seven strains hydrolyzing casein, in addition to the Penicillium fuscoglaucum strain. All the other fungal strains were negative for casein hydrolysis. Among the bacteria, five out of the nine Bacillus strains also hydrolyzed casein, as well as Cytobacillus oceanisediminis, Streptomyces thinghirensis, and Stagonosporopsis lupini.

The degradation of lipids is important in the Bacillus strains, of which six out of nine presented lipolytic activity, while only two out of the nine of Penicillium chrysogenum showed such activity, in addition to Penicillium fuscoglaucum and Botryotrichum domesticum. It should be noted that only the two strains of Bacillus paralicheniformis were capable of hydrolyzing gelatin.

Acid/alkali production was found in only five Bacillus strains. Calcite solubilization was very limited in the isolated strains and showed only in one strain of Penicillium chrysogenum and Penicillium fuscoglaucum. Gypsum solubilization was present in only three Bacillus strains.

Bacillus species generally produce enzymes such as lipases, proteases, xylanases, and others that allow for the breakdown of casein, gelatin, and lipids. Specifically, Bacillus cereus produces these types of enzymes. However, the strain isolated from Salón de Reinos does not possess these capacities, since it did not show hydrolytic activity against casein and lipids.

In light of the obtained data, the species with potential biodeterioration properties mainly belong to the genera Bacillus, Priestia, Cladosporium, and Penicillium, as described in other reports [2-5]. In addition, it should be noticed that airborne microorganisms, commonly isolated from plants, are able to use lipids and casein from mural paintings as nutrient sources and therefore represent a risk for mural paintings. 


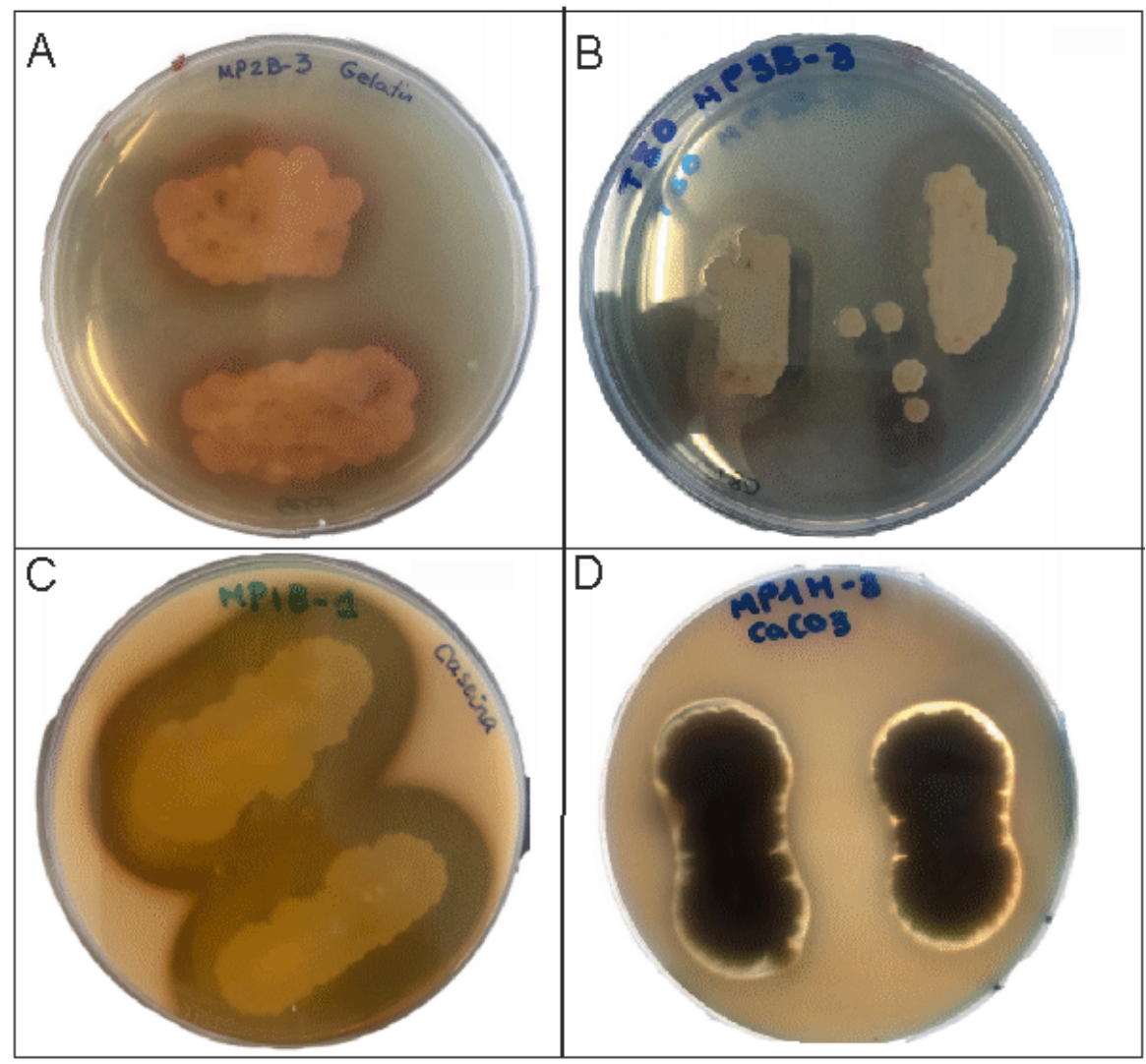

Figure 3. Metabolic activities of isolates. (A) Gelatin hydrolysis by Bacillus paralicheniformis. (B) Lipolytic activity by Priestia endophytica. (C) Casein hydrolysis by Priestia aryabhattai. (D) Calcite solubilization by Penicillium fuscoglaucum.

\subsection{Cleaning and Biocide Treatment}

When treating a biodeterioration, two different aspects must be taken into account: the elimination of the existing microorganisms and the prevention of new colonization.

The elimination of the effects of a biological attack is a delicate problem. If the growth is superficial, a mechanical cleaning and a soft biocide treatment should be effective. If the attack affected deep layers of the mural paintings, the fungal hyphae will be difficult to eliminate without affecting the painting, and for these situations an appropriate biocide is recommended.

The ideal biocide should have the following characteristics: broad spectrum of action at low concentrations, stability in solution, low vapor pressure to reduce evaporation, stability over time, and physical and chemical neutrality against the components of paints without action on the colors and texture of the paint.

One of the biocides most used by restorers and conservators in Italy [56-58] and also tested in Spain $[59,60]$ is Preventol RI 80, based on a quaternary ammonium salt. It is active against a wide variety of bacteria, fungi, algae, and lichens on stones and building materials $[57,59,61-63]$. Nevertheless, quaternary ammonium salts have shown, in a few cases, to be unsuitable, such as in subterranean environments (caves with rock art paintings) with high and constant relative humidity (above 90\%) [64,65]. However, these conditions are not present in the Salón de Reinos.

For the prevention of new biological attacks, an environmental control of the hall is needed. The main causes that favored the biodeterioration in the Salón de Reinos were the existence of fissures in the walls and water filtration that provoked the microbial growth. The restoration to be carried out will circumvent these problems.

Considering the variations due to the different compositions of the materials, the ideal conditions in which works of art (including wall paintings) should be preserved are a relative humidity of $40-65 \%$ and a temperature of $16-18^{\circ} \mathrm{C}$. These, or close, environmental 
conditions will prevent the growth and re-colonization of airborne microorganisms that can be deposited on the painted surfaces.

Bacteria need relative humidity $>95 \%$ and fungi need $75-95 \%$. In certain cases, some xerophilic microorganisms can grow at lower relative humidity. For this reason, the humidity limit in the Salón must never exceed values of $70 \%$ and the temperature must be maintained between 16 and $20^{\circ} \mathrm{C}$. If these conditions are maintained, the colonization and growth of microorganisms will be prevented. Once these conditions have been fixed, an additional precaution is the periodic cleaning of the painted surfaces (all this, of course, after the consolidation and restoration processes) to avoid the accumulation of dust particles and volatile and suspended organic matter as well as the deposition of airborne microorganisms.

As reported by Ágora, S.L., the microorganisms were eliminated using a protocol consisting of their mechanical removal with a natural bristle brush and the application of Preventol RI 80 at $0.5 \%$ in demineralized water, which has a broad spectrum in low concentrations on bacteria, fungi, algae, and lichens. This biocide is effective because it interferes with the enzymatic processes of the cell and modifies the permeability of its membrane. However, the sensitivity to quaternary ammonium salts depends on the species tested [55]. The intervention at the Salón de Reinos was focused mainly on the areas of superficial fungal colonies, showing black stains, and in specific areas of the lintels of three windows that were blinded on the south side of the hall.

One of the treatments that wall paintings may require is fixing and consolidation. Regardless of the type of fixative product that is most suitable for the case, there are some whose use is not recommended at all, among them the traditional organic fixatives, made up of natural protein-based products such as albumin and casein. Restorations with casein tend to cause microbial growth in the short term, since a high number of bacteria and fungi use it as a nutrient source, as shown in Table 5. Therefore, an acrylic-based micro-emulsion was used [66-68].

\section{Conclusions}

Three samples were studied: M1, dust obtained from the paint surface, and M2 and M3, microbial colonizations subjected to the influence of humidity. The results obtained are consistent with the nature of the samples. The dust sample shows an exclusive preponderance of species of the genus Bacillus among the bacteria, and a diversity of fungi, composed of the genera Penicillium, Cladosporium, Mucor, and Alternaria, with distribution consistent with the diversity of airborne fungal spores generally found in the air.

The two samples of black biofilms show different profiles, compatible with microbial colonization, in an advanced status in sample M3, an area favored by humidity. In this sample, a greater diversity is observed, both of bacteria (Bacillus, Cytobacillus, Streptomyces) and fungi (Penicillium, Mucor, Botryotrichum), which indicates a better development of the colonization, or a more advanced stage of deterioration. Sample M2 has intermediate characteristics, with the presence of Bacillus and only one species of fungus (Stagonosporopsis lupini).

The nature of the isolated microorganisms points to a high influence of airborne spores. Most isolated bacteria and fungi have their origin in plants-saprophytes or pathogensconsistent with the abundant vegetation in parks and gardens near the Museo Nacional del Prado (Retiro Park and Botanical Garden). Likewise, the presence of a few bacteria and fungi with biodeteriorative activities, previously detected in other murals and frescoes, is also noteworthy.

Author Contributions: Conceptualization, C.S.-J.; investigation, V.J., J.L.G.-P., B.H.; writing—original draft preparation, C.S.-J.; writing — review and editing, C.S.-J. All authors have read and agreed to the published version of the manuscript.

Funding: This research was funded by Ágora Restauraciones de Arte, S.L., Madrid, Spain.

Institutional Review Board Statement: Not applicable. 
Informed Consent Statement: Not applicable.

Data Availability Statement: Deposited in the NCBI GenBank database.

Acknowledgments: The authors wish to acknowledge the permission granted by Museo Nacional del Prado for this publication, the professional support of the CSIC Interdisciplinary Thematic Platform Open Heritage: Research and Society (PTI-PAIS), as well as the facilities of Ágora Restauraciones de Arte, S.L., and the help of Juan Aguilar.

Conflicts of Interest: The authors declare no conflict of interest.

\section{References}

1. Rosado, T.; Falé, A.; Gil, M.; Mirão, J.; Candeias, A.; Caldeira, A.T. Oxalate biofilm formation in mural paintings due to microorganisms-A comprehensive study. Int. Biodeter. Biodegr. 2013, 85, 1-7. [CrossRef]

2. Rosado, T.; Gil, M.; Caldeira, A.T.; Martins, M.R.; Dias, C.B.; Carvalho, L.; Mirão, J.; Candeias, A.E. Material characterization and biodegradation assessment of mural paintings: Renaissance frescoes from Santo Aleixo Church, Southern Portugal. Int. J. Archit. Herit. 2014, 8, 835-852. [CrossRef]

3. Rosado, T.; Falé, A.; Gil, M.; Mirão, J.; Candeias, A.; Caldeira, A.T. Understanding the influence of microbial contamination on colour alteration of pigments used in wall paintings-The case of red and yellow ochres and ultramarine blue. Color Res. Appl. 2019, 44, 783-789. [CrossRef]

4. Unković, N.; Grbić, M.L.; Stupar, M.; Savković, Ž.; Jelikić, A.; Stanojević, D.; Vukojević, J. Fungal-induced deterioration of mural paintings: In situ and mock-model microscopy analyses. Microsc. Microanal. 2016, 22, 410-421. [CrossRef] [PubMed]

5. Trovão, J.; Portugal, A. Current knowledge on the fungal degradation abilities profiled through biodeteriorative plate essays. Appl. Sci. 2021, 11, 4196. [CrossRef]

6. Piñar, G.; Saiz-Jimenez, C.; Schabereiter-Gurtner, C.; Blanco-Varela, M.T.; Lubitz, W.; Rölleke, S. Archaeal communities in two disparate deteriorated ancient wall paintings: Detection, identification and temporal monitoring by DGGE. FEMS Microbiol. Ecol. 2001, 37, 45-54. [CrossRef]

7. Gorbushina, A.A.; Heyrman, J.; Dornieden, T.; Gonzalez-Delvalle, M.; Krumbein, W.E.; Laiz, L.; Petersen, K.; Saiz-Jimenez, C.; Swings, J. Bacterial and fungal diversity and biodeterioration problems in mural painting environments of St. Martins church (Greene-Kreiensen, Germany). Int. Biodeter. Biodegr. 2004, 53, 13-24. [CrossRef]

8. Tsang, C.-C.; Chan, J.F.W.; Pong, W.-M.; Chen, J.H.K.; Ngan, A.H.Y.; Cheung, M.; Lai, C.K.C.; Tsang, D.N.C.; Lau, S.K.P.; Woo, P.C.Y. Cutaneous hyalohyphomycosis due to Parengyodontium album gen. et comb. nov. Med. Mycol. 2016, 54, 699-713. [CrossRef]

9. Saiz-Jimenez, C.; Samson, R.A. Microorganisms and environmental pollution as deteriorating agents of the frescoes of "Santa María de la Rábida," Huelva, Spain. In Proceedings of the 6th Triennial Meeting ICOM Committee for Conservation, Ottawa, Canada, 21-25 September 1981; p. 81/15/5.

10. Karpovich-Tate, N.; Rebrikova, N.L. Microbial communities on damaged frescoes and building materials in the cathedral of the Nativity of the Virgin in the Pafnutii-Borovskii monastery, Russia. Int. Biodeter. 1990, 27, 281-296. [CrossRef]

11. Gorbushina, A.A.; Petersen, K. Distribution of microorganisms on ancient wall paintings as related to associated faunal elements. Int. Biodeter. Biodegr. 2000, 46, 277-284. [CrossRef]

12. Jurado, V.; Sanchez-Moral, S.; Saiz-Jimenez, C. Entomogenous fungi and the conservation of the cultural heritage: A review. Int. Biodeter. Biodegr. 2008, 62, 325-330. [CrossRef]

13. Ma, Y.; Zhang, H.; Du, Y.; Tian, T.; Xiang, T.; Liu, X.; Wu, F.; An, L.; Wang, W.; Gu, J.-D.; et al. The community distribution of bacteria and fungi on ancient wall paintings of the Mogao Grottoes. Sci. Rep. 2015, 5, 7752. [CrossRef]

14. Ma, W.; Wu, F.; Tian, T.; He, D.; Zhang, Q.; Gu, J.-D.; Duan, Y.; Ma, D.; Wang, W.; Feng, H. Fungal diversity and its contribution to the biodeterioration of mural paintings in two 1700-year-old tombs of China. Int. Biodeter. Biodegr. 2020, 152, 104972. [CrossRef]

15. Duan, Y.; Wu, F.; Wang, W.; Gu, J.-D.; Li, Y.; Feng, H.; Chen, T.; Liu, G.; An, L. Differences of microbial community on the wall paintings preserved in situ and ex situ of the Tiantishan Grottoes, China. Int. Biodeter. Biodegr. 2018, 132, 102-113. [CrossRef]

16. He, D.; Wu, F.; Ma, W.; Zhang, Y.; Gu, J.-D.; Duan, Y.; Xu, R.; Feng, H.; Wang, W.; Li, S.-W. Insights into the bacterial and fungal communities and microbiome that causes a microbe outbreak on ancient wall paintings in the Maijishan Grottoes. Int. Biodeter. Biodegr. 2021, 163, 105250. [CrossRef]

17. Juretschko, S.; Timmermann, G.; Schmid, M.; Schleifer, K.-H.; Pommering-Röser, A.; Koops, H.-P.; Wagner, M. Combined molecular and conventional analyses of nitrifying bacterium diversity in activated sludge: Nitrosococcus mobilis and Nitrospira-like bacteria as dominant populations. Appl. Environ. Microbiol. 1998, 64, 3042-3051. [CrossRef] [PubMed]

18. Edwards, U.; Rogall, T.; Bliicker, H.; Emde, M.; Bottger, E.C. Isolation and direct complete nucleotide determination of entire genes. Characterization of a gene coding for $16 \mathrm{~S}$ ribosomal RNA. Nucleic Acids Res. 1989, 19, 7843-7853. [CrossRef] [PubMed]

19. White, T.J.; Bruns, T.; Lee, S.; Taylor, J. Amplification and direct sequencing of fungal ribosomal RNA genes for phylogenetics. In PCR, Protocols: A Guide to Methods and Applications; Innis, M.A., Gelfand, D.H., Sninsky, J.J., White, T.J., Eds.; Academic Press: New York, NY, USA, 1990; pp. 315-322.

20. Hall, T.A. BioEdit: A user-friendly biological sequence alignment editor and analysis program for Windows 95/98/NT. Nucleic Acids Symp. Ser. 1999, 41, 95-98. 
21. Altschul, S.F.; Gish, W.; Miller, W.; Myers, E.W.; Lipman, D.J. Basic local alignment search tool. J. Mol. Biol. 1990, 215, 403-410. [CrossRef]

22. Raja, H.A.; Miller, A.N.; Pearce, C.J.; Oberlies, N.H. Fungal identification using molecular tools: A primer for the natural products research community. J. Nat. Prod. 2017, 80, 756-770. [CrossRef] [PubMed]

23. Yoon, S.H.; Ha, S.M.; Kwon, S.; Lim, J.; Kim, Y.; Seo, H.; Chun, J. Introducing EzBioCloud: A taxonomically united database of 16S rRNA and whole genome assemblies. Int. J. Syst. Evol. Microbiol. 2017, 67, 1613-1617. [CrossRef] [PubMed]

24. Mazzoni, M.; Alisi, C.; Tasso, F.; Cecchini, A.; Marconi, P.; Sprocati, A.R. Laponite micro-packs for the selective celaning of multiple coherent deposits on wall paintings: The case study of Casina Farnese on the Palatine Hill (Rome-Italy). Int. Biodeter. Biodegr. 2014, 94, 1-11. [CrossRef]

25. Lanyi, B. Classical and rapid identification methods for medically important bacteria. In Methods in Microbiology; Colwell, R.R., Grigorova, R., Eds.; Academic Press: London, UK, 1987; pp. 1-67.

26. Unković, N.; Dimkić, I.; Supar, M.S.; Stanković, S.; Vukojević, J.; Grbić, M.L. Biodegradative potential of fungal isolates from sacral ambient: In vitro study as risk assessment implication for the conservation of wall paintings. PLoS ONE 2018, 13, e0190922. [CrossRef] [PubMed]

27. Bhattacharyya, C.; Bakshi, U.; Mallick, I.; Mukherji, S.; Bera, B.; Ghosh, A. Genome-guided insights into the plant growth promotion capabilities of the physiologically versatile Bacillus aryabhattai strain AB211. Front. Microbiol. 2017, 8, 411. [CrossRef]

28. Li, H.; Guan, Y.; Dong, Y.; Zhao, L.; Rong, S.; Chen, W.; Lv, M.; Xu, H.; Gao, X.; Chen, R.; et al. Isolation and evaluation of endophytic Bacillus tequilensis GYLH001 with potential application for biological control of Magnaporthe oryzae. PLoS ONE 2018, 13, e0203505. [CrossRef] [PubMed]

29. Liu, G.H.; Liu, B.; Wang, J.P.; Che, J.M.; Li, P.F. Reclassification of Brevibacterium frigoritolerans DSM 8801T as Bacillus frigoritolerans comb. nov. based on genome analysis. Curr. Microbiol. 2020, 77, 1916-1923. [CrossRef]

30. Dunlap, C.A.; Kwon, S.-W.; Rooney, A.P.; Kim, S.-J. Bacillus paralicheniformis sp. nov., isolated from fermented soybean paste. Int. J. Syst. Evol. Microbiol. 2015, 65, 3487-3492. [CrossRef] [PubMed]

31. Reva, O.N.; Smirnov, V.V.; Pettersson, B.; Priest, F.G. Bacillus endophyticus sp. nov., isolated from the inner tissues of cotton plants (Gossypium sp.). Int. J. Syst. Evol. Microbiol. 2002, 52, 101-107. [CrossRef]

32. Loqman, S.; Bouizgarne, B.; Barka, E.A.; Clément, C.; von Jan, M.; Spröer, C.; Klenk, H.-P.; Ouhdouch, Y. Streptomyces thinghirensis sp. nov., isolated from rhizosphere soil of Vitis vinifera. Int. J. Syst. Evol. Microbiol. 2009, 59, 3063-3067. [CrossRef] [PubMed]

33. Pepe, O.; Sannino, L.; Palomba, S.; Anastasio, M.; Blaiotta, G.; Villani, F.; Moschetti, G. Heterotrophic microorganisms in deteriorated medieval wall paintings in southern Italian churches. Microbiol. Res. 2010, 165, 21-32. [CrossRef] [PubMed]

34. Sugiyama, J.; Kiyuna, T.; Nishijima, M.; An, K.-D.; Nagatsuka, Y.; Tazato, N.; Handa, Y.; Hata-Yomita, J.; Sato, Y.; Kigawa, R.; et al. Polyphasic insights into the microbiomes of the Takamatsuzuka Tumulus and Kitora Tumulus. J. Gen. Appl. Microbiol. 2017, 63, 63-113. [CrossRef]

35. Tomassetti, M.C.; Cirigliano, A.; Arrighi, C.; Negri, R.; Mura, F.; Maneschi, M.L.; Gentili, M.D.; Stipe, M.; Mazzoni, C.; Rinaldi, T. A role for microbial selection in frescoes' deterioration in Tomba degli Scudi in Tarquinia, Italy. Sci. Rep. 2017, 7, 6027. [CrossRef] [PubMed]

36. Elhagrassy, A.F. Isolation and characterization of actinomycetes from mural paintings of Snu-Sert-Ankh tomb, their antimicrobial activity, and their biodeterioration. Microbiol. Res. 2018, 216, 47-55. [CrossRef] [PubMed]

37. Caneva, G.; Isola, D.; Lee, H.J.; Chung, Y.J. Biological risk for hypogea: Shared data from Etruscan tombs in Italy and ancient tombs of the Baekje dynasty in Republic of Korea. Appl. Sci. 2020, 10, 6104. [CrossRef]

38. Laiz, L.; Hermosin, B.; Caballero, B.; Saiz-Jimenez, C. Facultatively oligotrophic bacteria in Roman mural paintings. In Protection and Conservation of the Cultural Heritage of the Mediterranean Cities; Galan, E., Zezza, F., Eds.; Balkema: Lisse, The Netherlands, 2002; pp. 173-178.

39. Dominguez-Moñino, I.; Jurado, V.; Rogerio-Candelera, M.A.; Hermosin, B.; Saiz-Jimenez, C. Airborne bacteria in show caves from Southern Spain. Microb. Cell 2021, in press.

40. Srinath, B.S.; Namratha, K.; Byrappa, K. Green synthesis of biocompatible gold nanoparticles from gold mine bacteria Bacillus oceanisediminis and their antileukemic activity. Int. J. Pharm. Biol. Sci. 2018, 8, 169-177.

41. Nugari, M.P.; Realini, M.; Roccardi, A. Contamination of mural paintings by indoor airborne fungal spores. Aerobiologia 1993, 9 , 131-139. [CrossRef]

42. An, K.-D.; Kiyuna, T.; Kigawa, R.; Sano, C.; Miura, S.; Sugiyama, J. The identity of Penicillium sp. 1, a major contaminant of the stone chambers in the Takamatsuzuka and Kitora Tumuli in Japan, is Penicillium paneum. Anton. Leeuw. 2009, 96, 579-592. [CrossRef] [PubMed]

43. Ciferri, O. Microbial degradation of paintings. Appl. Environ. Microbiol. 1999, 65, 879-885. [CrossRef]

44. Woudenberg, J.H.C.; Seidl, M.F.; Groenewald, J.Z.; de Vries, M.; Thomma, B.P.H.J.; Crous, P.W. Alternaria section Alternaria: Species, formae speciales or pathotypes? Stud. Mycol. 2015, 82, 1-21. [CrossRef]

45. Bensch, K.; Groenewald, J.Z.; Dijksterhuis, J.; Starink-Willemse, M.; Andersen, B.; Summerell, B.A.; Shin, H.-D.; Dugan, F.M.; Schroers, H.-J.; Braun, U.; et al. Species and ecological diversity within the Cladosporium cladosporioides complex (Davidiellaceae, Capnodiales). Stud. Mycol. 2010, 67, 1-94. [CrossRef] [PubMed]

46. Bensch, K.; Groenewald, J.Z.; Meijer, M.; Dijksterhuis, J.; Jurjevic, Z.; Andersen, B.; Houbraken, J.; Crous, P.W.; Samson, R.A. Cladosporium species in indoor environments. Stud. Mycol. 2018, 89, 177-301. [CrossRef] 
47. Vaghefi, N.; Pethybridge, S.J.; Ford, R.; Nicolas, M.E.; Crous, P.W.; Taylor, P.W.J. Stagonosporopsis spp. associated with ray blight disease of Asteraceae. Australas. Plant Pathol. 2012, 41, 675-686. [CrossRef]

48. Ropars, J.; Didiot, E.; Rodríguez de la Vega, R.C.; Bennetot, B.; Coton, M.; Poirier, E.; Coton, E.; Snirc, A.; Le Prieur, S.; Giraud, T. Domestication of the emblematic white cheese-making fungus Penicillium camemberti and its diversification into two varieties. Curr. Biol. 2020, 30, 4441-4453. [CrossRef] [PubMed]

49. Saito, S.; Michailides, T.J.; Xiao, C.L. Mucor rot-An emerging postharvest disease of mandarin fuit caused by Mucor piriformis and other Mucor spp. in California. Plant Dis. 2016, 100, 1054-1063. [CrossRef]

50. Schultes, N.P.; Strzalkowski, N.; Li, D.-W. Botryotrichum domesticum sp. nov., a new hyphomycete from an indoor environment. Botany 2019, 87, 311-319. [CrossRef]

51. Pangallo, D.; Kraková, L.; Chovanová, K.; Šimonovicová, A.; De Leo, F.; Urzì, C. Analysis and comparison of the microflora isolated from fresco surface and from surrounding air environment through molecular and biodegradative assays. World J. Microbiol. Biotechnol. 2012, 28, 2015-2027. [CrossRef] [PubMed]

52. Pangallo, D.P.; Chovanová, K.C.; Šimonovicová, A.Š.; Ferianc, P.F. Investigation of microbial community isolated from indoor artworks and air environment: Identification, biodegradative abilities, and DNA typing. Can. J. Microbiol. 2009, 55, $277-287$. [CrossRef] [PubMed]

53. Savković, Ž.; Stupar, M.; Unković, N.; Ivanović, Ž.; Blagojević, J.; Vukojević, J.; Grbić, M.L. In vitro biodegradation potential of airborne Aspergilli and Penicillia. Sci. Nat. 2019, 106, 8. [CrossRef] [PubMed]

54. Trovão, J.; Tiago, I.; Catarino, L.; Gil, F.; Portugal, A. In vitro analyses of fungi and dolomitic limestone interactions: Bioreceptivity and biodeterioration assessment. Int. Biodeter. Biodegr. 2020, 155, 105107. [CrossRef]

55. Isola, D.; Zucconi, L.; Cecchini, A.; Caneva, G. Dark-pigmented biodeteriogenic fungi in etruscan hypogeal tombs: New data on their culture-dependent diversity, favouring conditions, and resistance to biocidal treatments. Fungal Biol. 2021, 125, 609-620. [CrossRef] [PubMed]

56. Bartolini, M.; Pietrini, A.M. La disinfezione delle patine biologiche sui manufatti lapidei: Biocidi chimici e naturali a confronto. Boll. ICR 2016, 33, 40-49.

57. Vannini, A.; Contardo, T.; Paoli, L.; Scattoni, M.; Favero-Longo, S.E.; Loppi, S. Application of commercial biocides to lichens: Does a physiological recovery occur over time? Int. Biodeter. Biodegr. 2018, 129, 189-194. [CrossRef]

58. Lo Schiavo, S.; De Leo, F.; Urzì, C. Present and future perspectives for biocides and antifouling products for stone-built cultural heritage: Ionic liquids as a challenging alternative. Appl. Sci. 2020, 10, 6568. [CrossRef]

59. Sanmartín, P.; Rodríguez, A.; Aguiar, U. Medium-term field evaluation of several widely used cleaning-restoration techniques applied to algal biofilm formed on a granite-built historical monument. Int. Biodeter. Biodegr. 2020, 147, 104870. [CrossRef]

60. Sanmartín, P.; Carballeira, R. Changes in heterotrophic microbial communities induced by biocidal treatments in the Monastery of San Martiño Pinario (Santiago de Compostela, NW Spain). Int. Biodeter. Biodegr. 2021, 156, 105130. [CrossRef]

61. Coutinho, M.L.; Miller, A.Z.; Martin-Sanchez, P.M.; Mirao, J.; Gomez-Bolea, A.; Machado-Moreira, B.; Cerqueira-Alves, L.; Jurado, V.; Saiz-Jimenez, C.; Lima, A.; et al. A multiproxy approach to evaluate biocidal treatments on biodeteriorated majolica glaze tiles. Environ. Microbiol. 2016, 18, 4794-4816. [CrossRef] [PubMed]

62. Romani, M.; Warscheid, T.; Nicole, L.; Marcon, L.; Di Martino, P.; Suzuki, M.T.; Lebaron, P.; Lami, R. Current and future chemical treatments to fight biodeterioration of outdoor building materials and associated biofilms: Moving away from ecotoxic and towards efficient, sustainable solutions. Sci. Total. Environ. 2021, 802, 149846. [CrossRef]

63. Presentato, A.; Armetta, F.; Spinella, A.; Chillura Martino, D.F.; Alduina, R.; Saladino, M.L. Formulation of mesoporous silica nanoparticles for controlled release of antimicrobials for stone preventive conservation. Front. Chem. 2020, 8, 699. [CrossRef]

64. Bastian, F.; Alabouvette, C.; Saiz-Jimenez, C. Impact of biocide treatments on the bacterial communities of the Lascaux Cave. Naturwissenschaften 2009, 96, 863-868. [CrossRef]

65. Martin-Sanchez, P.M.; Nováková, A.; Bastian, F.; Alabouvette, C.; Saiz-Jimenez, C. Use of biocides for the control of fungal outbreaks in subterranean environments: The case of the Lascaux Cave in France. Environ. Sci. Technol. 2012, 46, 3762-3770. [CrossRef] [PubMed]

66. Camaiti, M.; Borgioli, L.; Rosi, L. Photostability of innovative formulations for artworks restoration. Chim. Ind. 2011, 9, 100-195.

67. Gheno, G.; Badetti, E.; Brunelli, A.; Ganzerla, R.; Marcomini, A. Consolidation of Vicenza, Arenaria and Istria stones: A comparison between nano-based products and acrylate derivatives. J. Cult. Herit. 2018, 32, 44-52. [CrossRef]

68. Negri, A.; Nervo, M.; Di Marcello, S.; Castelli, D. Consolidation and adhesion of pictorial layers on a stone substrate. The study case of the Virgin with the Child from Palazzo Madama, in Turin. Coatings 2021, 11, 624. [CrossRef] 